DOE/OR/01-1291\&D1

\title{
Annual Status Report on Federal Facility Agreement Compliance for the Liquid Low-Level Waste Tank Systems at Oak Ridge National Laboratory
}

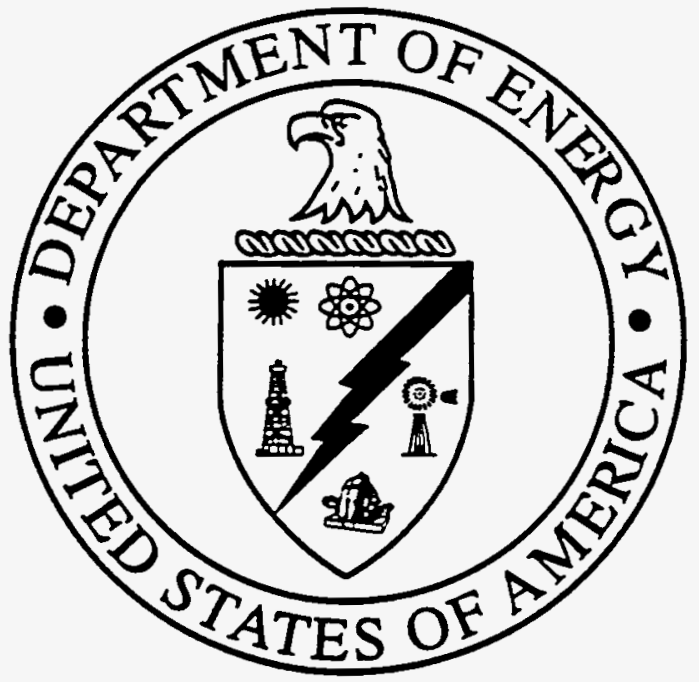




\begin{tabular}{l} 
H\&R Technical Associates, Inc. \\
$\begin{array}{l}\text { contributed to the preparation of this document and } \\
\text { should not be considered an eligible contractor for its } \\
\text { review. }\end{array}$ \\
\hline
\end{tabular}

This report has been reproduced directly from the best available copy.

Available to DOE and DOE contractors from the Office of Scientific and Technical Information, P.O. Box 62, Oak Ridge, TN 37831; prices available from 615-576-8401.

Available to the public from the National Technical Information Service, U.S. Department of Commerce, 5285 Port Royal Rd., Springfield, VA 22161. 


\section{DISCLAIMER}

This report was prepared as an account of work sponsored by an agency of the United States Government. Neither the United States Government nor any agency thereof, nor any of their employees, make any warranty, express or implied, or assumes any legal liability or responsibility for the accuracy, completeness, or usefulness of any information, apparatus, product, or process disclosed, or represents that its use would not infringe privately owned rights. Reference herein to any specific commercial product, process, or service by trade name, trademark, manufacturer, or otherwise does not necessarily constitute or imply its endorsement, recommendation, or favoring by the United States Government or any agency thereof. The views and opinions of authors expressed herein do not necessarily state or reflect those of the United States Government or any agency thereof. 


\section{DISCLAIMER}

Portions of this document may be illegible in electronic image products. Images are produced from the best available original document. 


\section{Annual Status Report on Federal Facility Agreement Compliance for the Liquid Low-Level Waste Tank Systems at Oak Ridge National Laboratory}

Date Issued-September 1994

Prepared by

Waste Management and Remedial Actions Division

Oak Ridge National Laboratory

Prepared for

U.S. Department of Energy

Office of Environmental Restoration and Waste Management under budget and reporting code EW 20

Environmental Restoration and Waste Management Programs

Oak Ridge National Laboratory

Oak Ridge, Tennessee 37831-6285

managed by

MARTIN MARIETTA ENERGY SYSTEMS, INC.

for the

U.S. DEPARTMENT OF ENERGY

under contract DE-AC05-84OR21400 



\section{CONTENTS}

EXECUTIVE SUMMARY $\ldots \ldots \ldots \ldots \ldots \ldots \ldots \ldots \ldots \ldots$ v

1. INTRODUCTION $\ldots \ldots \ldots \ldots \ldots \ldots \ldots \ldots \ldots \ldots \ldots \ldots$

2. FFA DELIVERABLES AND COMMTTMENTS $\ldots \ldots \ldots \ldots \ldots \ldots$

2.1 DESIGN ASSESSMENT FOR FFA COMPLIANCE WORK IN

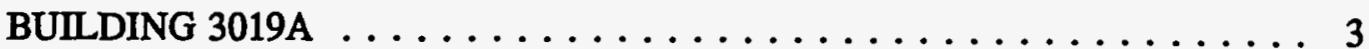

2.2 DESIGN DEMONSTRATIONS FOR CATEGORY B PIPELINES $\ldots \ldots \ldots 3$

2.3 DESIGN ASSESSMENT FOR THE MELTON VALLEY LLLW-CAT LINE ITEM PROJECT $\ldots \ldots \ldots \ldots \ldots \ldots \ldots \ldots \ldots \ldots$

2.4 FFA PLANS AND SCHEDULES UPDATE $\ldots \ldots \ldots \ldots \ldots \ldots \ldots \ldots$

2.5 ANNUAL COMPLIANCE STATUS DOCUMENT $\ldots \ldots \ldots \ldots \ldots \ldots \ldots$

2.6 DESIGN DEMONSTRATION FOR REMAINING 19 CATEGORY B TANK SYSTEMS $\ldots \ldots \ldots \ldots \ldots \ldots \ldots \ldots \ldots \ldots$

2.7 DESIGN DEMONSTRATIONS FOR CATEGORY B TANK SYSTEMS $\ldots \ldots 5$

3. FFA PROJECT STATUS $\ldots \ldots \ldots \ldots \ldots \ldots \ldots \ldots \ldots \ldots \ldots$

3.1 LINE ITEM PROJECTS $\ldots \ldots \ldots \ldots \ldots \ldots \ldots \ldots \ldots \ldots \ldots$

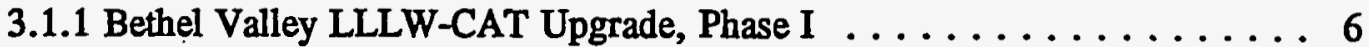

3.1.2 Bethel Valley LLLW-CAT Upgrade, Phase II . . . . . . . . . 6

3.1.3 Melton Valley LLLW-Collection and Transfer

System Upgrade $\ldots \ldots \ldots \ldots \ldots \ldots \ldots \ldots \ldots \ldots \ldots \ldots \ldots \ldots$

3.1.4 Bethel Valley FFA Upgrades . . . . . . . . . . . . 7

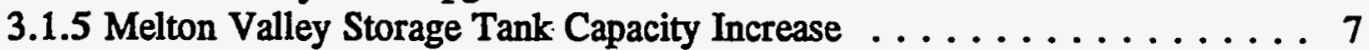

3.2 GENERAL PLANT PROJECTS (GPP) $\ldots \ldots \ldots \ldots \ldots \ldots \ldots \ldots \ldots$

3.2.1 FFA Compliance Work, Building 3019A $\ldots \ldots \ldots \ldots \ldots \ldots \ldots 7$

3.2.2 BSR/ORR LLLW Upgrade $\ldots \ldots \ldots \ldots \ldots \ldots \ldots \ldots \ldots \ldots$

3.2.3 7930 Filter Pit Cover $\ldots \ldots \ldots \ldots \ldots \ldots \ldots \ldots \ldots$

3.2.4 New Hydrofracture Cell Plugs Enclosures $\ldots \ldots \ldots \ldots \ldots \ldots \ldots 8$

3.2.5 Incinerator Drive Valve Box Upgrade $\ldots \ldots \ldots \ldots \ldots \ldots \ldots .8$

3.2.6 W-6 Valve Box Upgrade ................... 9

3.2.7 East Evaporator Valve Pit Upgrade . . . . . . . . . . . 9

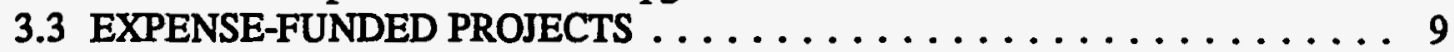

3.4 SOURCE TREATMENT AND PRETREATMENT PROJECTS ........99

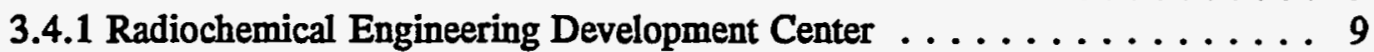

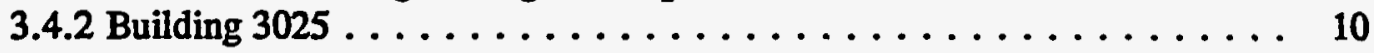

4. LEAK TESTING $\ldots \ldots \ldots \ldots \ldots \ldots \ldots \ldots \ldots \ldots \ldots \ldots \ldots \ldots \ldots$

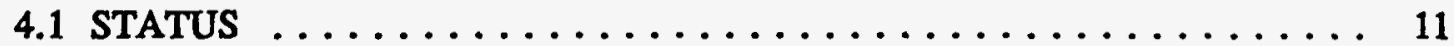

4.2 ACCOMPLISHMENTS $\ldots \ldots \ldots \ldots \ldots \ldots \ldots \ldots \ldots \ldots \ldots \ldots$

4.3 SCOPE OR SCHEDULE CHANGES $\ldots \ldots \ldots \ldots \ldots \ldots \ldots \ldots \ldots 11$

5. OTHER FFA ACTIVITIES, CONCERNS, AND ISSUES $\ldots \ldots \ldots \ldots \ldots \ldots$

5.1 IMPROVED COMMUNICATION SYSTEM $\ldots \ldots \ldots \ldots \ldots \ldots \ldots \ldots, 12$

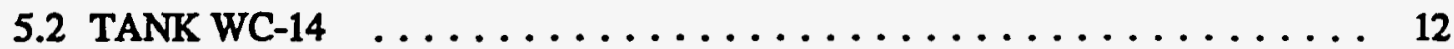

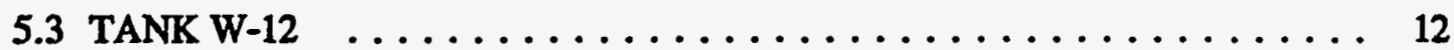

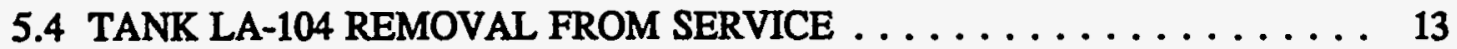


5.5 TECHNICAL ADVISORY GROUP $\ldots \ldots \ldots \ldots \ldots \ldots \ldots \ldots 13$

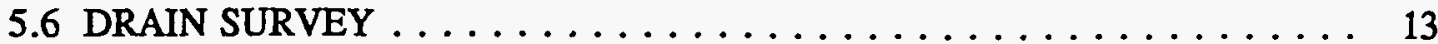

5.7 ENVIROVIEW SOFTWARE $\ldots \ldots \ldots \ldots \ldots \ldots \ldots \ldots \ldots \ldots$

5.8 TANK WC-9 LEVEL 2 OCCURRENCE $\ldots \ldots \ldots \ldots \ldots \ldots \ldots \ldots 13$

5.93039 STACK/SOTOPES AREA DRAIN CLOSURE . . . . . . . . . 14

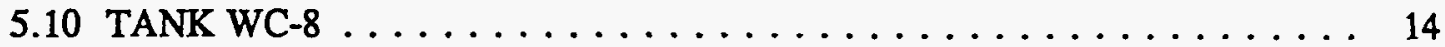

5.11 30-DAY REPORTS . . . . . . . . . . . . . . . . 14

5.12 ELIMINATION OF NONPROGRAMMATIC FLOW $\ldots \ldots \ldots \ldots \ldots 14$

5.13 TANK F-501 ...................... 15

5.14 CONTINGENCY PLANNING FOR THE GUNITE TANKS $\ldots \ldots \ldots \ldots 15$

5.15 CATEGORY D TANK EXAMINATIONS $\ldots \ldots \ldots \ldots \ldots \ldots \ldots$

APPENDIX A. PERFORMANCE INDICATORS $\ldots \ldots \ldots \ldots \ldots \ldots \ldots \ldots$ A-1

\section{FIGURES}

1 Submittal dates to EPA and TDEC for FY 1994

FFA deliverables compared to milestone dates

2

\section{TABLES}

1 Tank leak test results. $\ldots \ldots \ldots \ldots \ldots \ldots \ldots \ldots \ldots \ldots \ldots \ldots \ldots \ldots \ldots \ldots \ldots$

2 Pipeline leak test results $\ldots \ldots \ldots \ldots \ldots \ldots \ldots \ldots \ldots \ldots \ldots \ldots \ldots \ldots \ldots$ 


\section{EXECUTIVE SUMMARY}

This annual report summarizes the status of Federal Facility Agreement (FFA) compliance activities at Oak Ridge National Laboratory (ORNL) and describes the progress made over the past fiscal year.

In fiscal 1994, ORNL issued the final submittal of the risk characterization data for the inactive tanks, the secondary containment design demonstration report for Category B piping, and the FFA Implementation Plan. In addition, two new LLLW tanks serving Building 2026 and the Transported Waste Receiving Facility were installed; leak testing was initiated for all active, singly contained tanks and piping; sources of inflow to inactive tanks were investigated and diversion to process waste was begun; and the W-12 tank system was repaired and a request to allow its temporary use was approved by EPA/TDEC. Programmatic improvements were also made during the year: a system for improved communication of FFA plans and activities was implemented in October 1993, a survey was conducted to ensure that all inactive drains are identified and sealed, and two meetings of the ORNL FFA Technical Advisory Group were held. 


\section{INTRODUCTION}

This annual report summarizes the status of Federal Facility Agreement (FFA) compliance activities at Oak Ridge National Laboratory (ORNL) and describes the progress made over the past fiscal year. Requirements in the Comprehensive Environmental Response, Compensation, and Liability Act, as amended by the Superfund Amendments and Reauthorization Act, resulted in the FFA between the U.S. Environmental Protection Agency (EPA), the U.S. Department of Energy (DOE), and the Tennessee Department of Environment and Conservation (TDEC) for the investigation and remediation of environmental impacts from past and present activities on the Oak Ridge Reservation. This FFA went into effect on January 1, 1992. Its primary impact on ORNL results from its requirements on the design and operation of the Liquid Low-Level Radioactive Waste (LLLW) System which are contained in FFA Section IX.

In fiscal 1994, ORNL issued the remaining risk characterization data for the inactive tanks, the secondary containment design demonstration report for Category B piping, and the FFA Implementation Plan. In addition, two new LLLW tanks serving Building 2026 and the Transported Waste Receiving Facility were installed; leak testing was initiated for all active, singly contained tanks and piping; sources of inflow to inactive tanks were investigated and diversion to process waste was begun; and the W-12 tank system was repaired and a request to allow its temporary use was approved by EPA and TDEC. Programmatic improvements were also made during the year: a system for improved communication of FFA plans and activities was implemented in October 1993, a survey was conducted to ensure that all inactive drains are identified and sealed, and two meetings of the ORNL FFA Technical Advisory Group were held. 


\section{FFA DELIVERABLES AND COMMITMENTS}

ORNL FY 1994 FFA milestones as reflected in Appendix E of the FFA are as follows:

- Design and Installation Assessment for FFA Compliance Work, Building

$1 / 31 / 94$ 3019A

- Design Demonstrations for Category B pipelines

- Design and Installation Assessment for Melton Valley LLLW-Collection and 5/31/94 Transfer (CAT) system line item

- Plans and Schedules Document (Implementation Plan)

- Annual Compliance Status

DOE has been attempting to deliver FY 1994 FFA documents ahead of the milestone date. A comparison of actual submittal dates to EPA and TDEC as compared to the milestone dates is shown in Fig. 1.

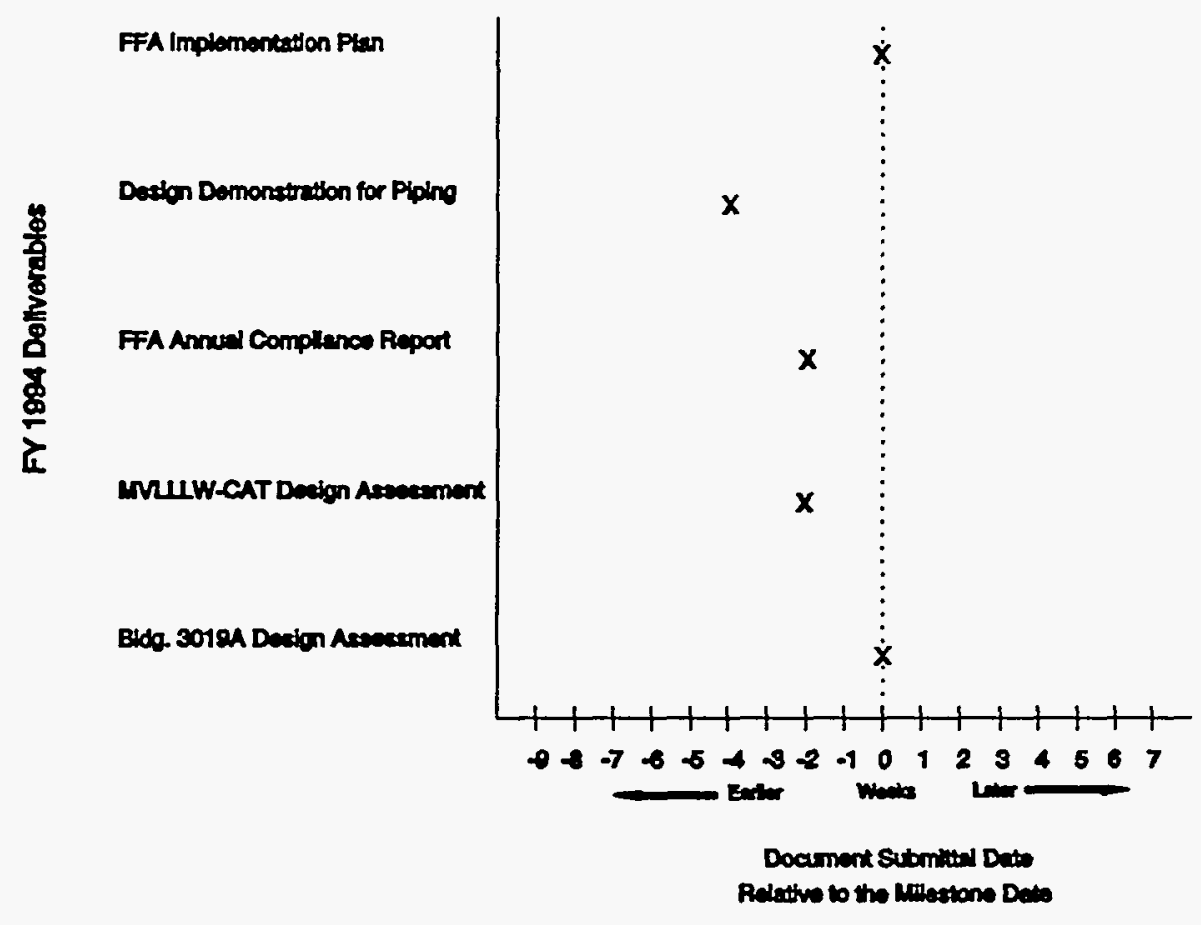

Fig. 1. Submittal dates to EPA and TDEC for FY 1994 FFA deliverables compared to milestone dates. 


\subsection{DESIGN ASSESSMENT FOR FFA COMPLIANCE WORK IN BUILDING 3019A}

The design assessment for the FFA compliance work in Building 3019A was initially issued to EPA and TDEC for comment in January 1994 (DOE/OR/03-1097\&D1). EPA and TDEC comments were incorporated into the D2 submittal, which was sent to EPA and TDEC in July. The D2 package consisted of the compliance certification, the construction specifications, and a project drawing list. The comments dealt primarily with corrosion protection, including testing for factors A through F in FFA Appendix F (which affect the potential for corrosion); the correctness of statements that certain FFA requirements are not applicable; and the calculations that support the conclusions of the design assessment.

In response to EPA and TDEC comments, the D2 submittal clarifies that corrosion protection for the piping meets the requirements of the FFA, including Appendix F factors A through $\mathrm{H}$ inclusive. In addition, the supporting calculations (CIV-ERWM-070) were provided for EPA and TDEC review. EPA and TDEC approved the D2 revision of the document in July.

\subsection{DESIGN DEMONSTRATIONS FOR CATEGORY B PIPELINES}

The D1 version of the secondary containment Design Demonstrations report for Category B pipelines (DOE/OR/03-1195\&D1) was submitted to EPA and TDEC in February, more than 30 days in advance of the milestone date. Comments from EPA and TDEC were received on May 23, and responses to comments were submitted in July. The EPA and TDEC comments dealt primarily with the plans and schedules for upgrading or replacing singly contained piping segments; cathodic protection for buried components; the compatibility of containment materials with the waste contained therein; the need for active leak detection capability; the ability of the containment systems to drain and remove liquids from spills, leaks, or precipitation; chemically resistant water stops; and the presence of singly contained, embedded piping.

Plans and schedules for upgrading or replacing systems and components that do not meet FFA requirements were developed and submitted to EPA and TDEC in March 1992 in the FFA plans and schedules document (ES/ER-17\&D1). The plans and schedules were updated in the June 1994 issue of the Implementation Plan (DOE/OR/01-1276\&D1). The revised design demonstration report for the Category $B$ pipelines cites these plans and schedules. The revised design demonstration report also cites the replacement and upgrade projects that will provide cathodic protection for buried components and correct noted deficiencies in secondary containment, secondary containment liner or coating incompatibility, leak detection, and removal means for leaks, spills, and precipitation. DOE stated in responding to EPA and TDEC comments that an evaluation is being prepared to assess the risk to human health from the embedded pipes in their current configuration and to compare that to the risk from replacing the existing embedded pipes with double-walled pipes. DOE will recommend a course of action for the embedded piping to EPA and TDEC on the basis of the risk associated with each option.

\subsection{DESIGN ASSESSMENT FOR THE MELTON VALLEY LLLW COLLECTION AND TRANSFER SYSTEM UPGRADE LINE ITEM PROJECT}

The design assessment for the Melton Valley LLLW-CAT (MVLLLW-CAT) System Upgrade line item project (DOE/OR/03-1258\&D1) was completed and submitted to EPA and TDEC on May 19, 1994, approximately 2 weeks ahead of the milestone schedule. The package 
consisted of the PE-stamped compliance certification, a listing of design drawings for the project, and copies of the design drawings. The assessment determined that the project meets all applicable FFA requirements. Upon receipt of comments, if any, from EPA and TDEC, DOE will revise and reissue the assessment.

\subsection{FFA PLANS AND SCHEDULES UPDATE}

The FFA plans and schedules document, which transmitted required information to EPA and TDEC in March 1992, contains plans and schedules that are approved by EPA and TDEC for ORNL compliance activities. Consequently, that document is not suitable for use as a status report that is regularly updated and reissued. Instead, the FFA implementation plan (DOE/OR/011276\&D1) was prepared and submitted to EPA and TDEC in June 1994. The implementation plan is an informational document that will be revised periodically to summarize the progress and update the status of FFA activities.

\subsection{ANNUAL COMPLIANCE STATUS DOCUMENT}

This report constitutes the annual compliance status document that must be submitted to EPA and TDEC by September 30, in accordance with the milestone schedule in Appendix $E$ of the FFA.

\subsection{DESIGN DEMONSTRATION FOR REMAINING 19 CATEGORY B TANK SYSTEMS}

Though not a milestone deliverable for FY 1994, responses to EPA and TDEC comments on the design demonstration report for the 19 remaining Category B tank systems (DOE/OR/031150) were submitted to the regulators in January. The comments dealt primarily with chemicalresistant water stops in several tank vaults, exterior moisture barriers for the vaults, prevention of infiltration from precipitation, vault liners, vault ventilation, and why some tanks that handle waste are not included in the LLLW System. The responses to these comments are summarized in the following paragraphs.

Although the waterstops provided in the tank vault joints were not specified as chemically resistant, vault construction meets the intent of the FFA-the exteriors are waterproofed, the interiors are coated, and the vaults are provided with alarmed leak detection systems so that neither LLLW nor groundwater are likely to contact the waterstops.

To prevent precipitation from infiltrating the vaults, plans are in place to provide covers over the vaults for Tanks B-2-T, B-3-T, C-6-T, and T-13 and the 7930 filter pit.

The lack of an exterior moisture barrier on the vaults is mitigated by a site drainage system on the walls that contact the soil. The drainage system is designed to minimize groundwater infiltration into the vaults.

Full vault liners are not needed because the existing liners are designed to contain the capacity of the largest tank in the vault. 
Vault ventilation to prevent the buildup of flammable vapor is not needed because the tanks have positive ventilation.

All tanks that handle low-level waste are not considered LLLW tanks. Many process tanks collect liquid and recycle it back to the process. LLLW tanks collect waste solely in preparation for transferring it to the central LLLW System. The list of LLLW tanks in FFA Appendix F is correct.

\subsection{DESIGN DEMONSTRATIONS FOR CATEGORY B TANK SYSTEMS}

The Design Demonstrations for Category B Tank Systems report (DOE/OR-1047\&D1) was submitted to EPA and TDEC early in FY 1994. The regulators agreed with the demonstration report that tanks W-21 through W-31 meet the requirements of FFA Appendix F, Section C. 


\section{FFA PROJECT STATUS}

Several line item, general plant, and expense-funded projects are planned or are underway to bring the LLLW System into compliance with FFA requirements. These projects and their schedules are discussed in the ORNL FFA plans and schedules document and the FFA Implementation Plan Document. In this section, the scope of each project is briefly described and the activities that took place in FY 1994 are summarized. The funding year for each capital project appears in the appropriate section title.

\subsection{LINE ITEM PROJECTS}

\subsubsection{Bethel Valley LLLW-CAT Upgrade, Phase I (WBS 3.37), FY 1988}

During Phase I of the Bethel Valley LLLW-CAT Upgrade (BVLLLW-CAT) project, a monitoring and control station (MCS) was installed and part of the LLLW system piping inside Building 2026 was upgraded to meet FFA requirements. In addition, the Transported Waste Receiving Facility (TWRF) was constructed during Phase I.

In FY 1994, construction and testing of the MCS (Building 2099) was completed. Interior LLLW piping for hot cells 1-4 in Building 2026 was completed. Installation of the piping from Building 2026 to Building 2099 and from 2099 to new Valve Box 1A was completed. Construction of the TWRF was completed, and construction on Valve Box VB-3A, which provides the connection between the LLLW evaporators and the TWRF, was started. Project completion is scheduled for this fiscal year.

\subsection{Bethel Valley LLLW-CAT Upgrade, Phase II (WBS 3.37), FY 1988}

During BVLLLW-CAT Phase II, an MCS will be constructed for Building 3525 and the Central Off-Gas Scrubber (3092), and the upgrade of LLLW piping in Building 2026 will be completed. Tank system 2026A will then be removed from service. Project completion is scheduled for FY 1997.

Review of the design package started in FY 1994.

\subsubsection{Melton Valley LLLW-CAT System Upgrade (WBS 3.45), FY 1992}

The MVLLLW-CAT system collects and neutralizes LLLW generated by the High Flux Isotopes Reactor (HFIR) and the Radiochemical Engineering Development Center (REDC) before the LLLW is pumped to Bethel Valley for processing. Parts of the existing system do not meet the requirements of the FFA for long-term operation. The MVLLLW-CAT System Upgrade project will upgrade deficient parts of the existing system and install a new MCS that employs doubly contained collection and transfer tanks and piping, active leak detection, and corrosion protection for underground components. In addition, a new valve box will be provided to permit waste transfer between the REDC buildings and the MCS, and the singly contained line that crosses the ridge from Melton Valley to Bethel Valley will be replaced.

Through the MVLLLW-CAT project, tank systems B-2-T, B-3-T, and C-6-T serving Building 7930 and tank systems F-111 and F-126 serving Building 7920 will be upgraded to 
meet all FFA requirements. In addition, ion exchange columns and a new filter house will be added to eliminate LLLW generation by HFIR. Once LLLW is eliminated from HFIR, Category C tanks HFIR, T-1, and T-2 can be taken out of service. Project completion is scheduled for FY 1996.

Construction started at the HFIR this fiscal year.

\subsubsection{Bethel Valley FFA Upgrades (WBS 3.31), FY 1994}

Through the Bethel Valley FFA Upgrades project, the LLLW System for Buildings 3503 and 3025 will be replaced by FY 1998. Hot off-gas filter pits 2533 and 2534 will be replaced by above-ground, high-efficiency particulate air (HEPA) filters with shield walls, thereby eliminating these filter pits as sources of LLLW. Project completion is scheduled for FY 1998.

During the past year, the design criteria for the project were issued, the Title I design $30 \%$ design review was conducted, and the value engineering study for the project was completed. Several design and administrative changes that were implemented resulted in cost savings and operational improvements. The project scope for Building 3025 was revised. Instead of installing a doubly contained line from the building to the BVLLLW-CAT MCS, the line will be routed to valve box VB-1A and a tie-in to the LLLW system made at that point. This change will result in LLLW being pumped from the building rather than transferred by gravity flow as originally planned. The change also requires the addition of a small holdup tank in Building 3025. The reasons for this change are twofold: (1) the location of the MCS was changed and (2) the rerouted piping results in a reduction in the volume of waste soil to be generated. The design assessment for this project is scheduled for submittal to EPA and TDEC in the fourth quarter of FY 1995.

\subsubsection{Melton Valley Storage Tank Capacity Increase (WBS 3.46), FY 1994}

Through this line item project, additional LLLW storage tanks that meet FFA requirements will be constructed. A facility will be built that consists of six lined vaults, each containing one 100,000-gal LLLW storage tank; a lined pipe vault; a HEPA-filter ventilation system; a valve pit that connects the new piping to the existing Melton Valley Storage Tank system; a truck unloading facility for handling tankers; and control and equipment rooms to house support equipment. Project completion is scheduled for FY 1998.

In FY 1994, work on the environmental assessment (EA) for the project neared completion. Also in FY 1994, the Project Plan was approved, Title II design was started, and procurement of long-lead-time items was begun. The design assessment for this project is scheduled for submittal to EPA and TDEC in the third quarter of FY 1995.

\subsection{GENERAL PLANT PROJECTS (GPP)}

\subsubsection{FFA Compliance Work, Building 3019A (WBS 3.28), FY 1992}

The piping that connects Building 3019A, the Radiochemical Processing Pilot Plant, to the central LLLW System does not meet FFA requirements for secondary containment. Through this GPP, piping inside the building will be modified to route LLLW to an existing 1.5-in.-diameter pipe in a stainless-steel-lined concrete conduit. This existing conduit runs from the south wall of the building south toward Central Avenue. The conduit passes about $60 \mathrm{ft}$ west of Valve Box 1A 
at one point. At this location, a new valve box, 1B, will be constructed around the conduit, and a new double-walled pipe will be connected to the existing 1.5 -in. line. From Valve Box $1 \mathrm{~B}$, the new pipe will be routed underground to Valve Box 1A, where the pipe will connect to fully FFAcompliant piping in the LLLW System. The new valve box will be equipped with a sump and a steam jet to collect any LLLW leaks and route them back to the system. This new arrangement will fully meet FFA requirements. Project completion is scheduled for FY 1996.

In FY 1994, design was completed for the new piping, modifications to existing piping, and valve boxes. Construction activities also began in FY 1994.

\subsubsection{BSR/ORR LLLW Upgrade (WBS 3.79), FY 1992}

The Bulk Shielding Reactor and the Oak Ridge Research Reactor were placed in standby status in 1987 to await decommissioning. In standby mode, the water quality in the pools of both reactors must be maintained. The existing ion exchange columns for each facility route regeneration waste to the LLLW System through tanks and piping that do not meet FFA requirements for long-term operation. The purpose of this GPP is to provide the equipment needed to continuously add fresh deionized water to the pools at a rate sufficient to maintain water quality and send the overflow to the Process Waste Treatment Plant, thereby eliminating the generation of LLLW from this source. Project completion is scheduled for FY 1995.

Procurement was started this fiscal year.

\subsubsection{Filter Pit Cover (WBS 2.29), FY 1993}

Rainwater leaks into the off-gas filter pit that serves Building 7930. This water is collected in a sump and routed to the LLLW System. Through this GPP, a sheet metal structure equipped with a removable roof will be installed over the filter pit to eliminate the inleakage. A personnel access door, fire alarm system, lighting, and electrical service will be provided in the structure. Project completion is scheduled for FY 1995.

During FY 1994, design for the filter pit cover was completed, and the installation contract was awarded.

\subsubsection{New Hydrofracture Cell Plugs Enclosures (WBS 2.10), FY 1994}

The concrete access plugs in the containment enclosures in the New Hydrofracture Facility are not weathertight, and rainwater leaks into the cells. Through this GPP, enclosures will be provided for the cell and vault access plugs at Building 7860, T-13 vault, and the MVSTs to eliminate the inleakage of rain water. Project completion is scheduled for FY 1995.

Design of the enclosures was completed in FY 1994.

\subsubsection{Incinerator Drive Valve Box Upgrade (WBS 3.24), FY 1994}

The Incinerator Drive Valve Box does not meet the FFA requirements for secondary containment. Through this GPP, a stainless steel liner with a sump and leak detection instruments will be installed in the valve box. Interconnecting Pipeline Valve Box \#1 (ICPL \#1) will also be upgraded through this project. Project completion is scheduled for FY 1995. 
In FY 1994, design was initiated and the risk mitigation assessment/plan was completed. The project records plan, the QA evaluation, the safety assessment, the project waste management plan, and the project design package were also completed during this fiscal year.

\subsubsection{W-6 Valve Box Upgrade (WBS 3.22), FY 1995}

The W-6 valve box does not meet FFA requirements for secondary containment. Through this GPP, a stainless steel liner with a sump and leak detection instruments will be installed in the valve box. Project completion is scheduled for FY 1997.

During this fiscal year, supporting documents including the functional requirements document, the risk mitigating actions plan, the waste management plan, the QA evaluation, the safety assessment, and the project records plan were completed. Title I design was also initiated in FY 1994.

\subsubsection{East Evaporator Valve Pit Upgrade (WBS 3.23), FY 1995}

Through the East Evaporator Valve Pit (EAVP) Upgrade GPP, leak detection will be provided for the EAVP. The valve pit east of the Evaporator (also know as Evaporator Annex Valve Pit \#1) will also be upgraded. Project completion is scheduled for FY 1997.

Supporting documents, including the functional requirements document, the risk mitigating actions plan, the waste management plan, the QA evaluation, the safety assessment, and the project records plan, were completed this fiscal year.

\subsection{EXPENSE-FUNDED PROJECTS}

The Building 3517 LLLW Upgrade expense-funded project installs a valve in the LLLW line immediately inside Cell 25 so the line can be pressure tested. Project completion is scheduled for this fiscal year.

During FY 1994, Health Physics technicians determined that radiation levels in Cell 25 were too high for personnel safety. To enable the work to proceed, localized shielding was fabricated and installed. All preparatory work for installing the valve was completed this fiscal year, including design, receipt of purchased materials, shop fabrication, and drafting of the required planning and scheduling documents and installation procedures.

\subsection{SOURCE TREATMENT AND PRETREATMENT PROJECTS}

\subsubsection{Radiochemical Engineering Development Center}

Source treatment studies have been undertaken at the REDC to meet the need for a contingency plan should access to the LLLW System be lost due to failure of the singly contained piping to meet the leak test requirements or due to a delay in construction activities. During FY 1994, two principal work elements were planned: (1) provision of a trucking station for shipping REDC liquid waste to the LLLW evaporator and (2) development of a decantation/filtration system for removing strontium and other insoluble radionuclides so that the waste can be shipped as low-specific-activity (LSA) waste. Project completion is scheduled for FY 1995. 
In FY 1994, conceptual design studies showed that the tanker truck used to transport LSA waste at ORNL is not compatible with the waste collection system at REDC. Consequently, construction of a station for cask shipment rather than the planned trucking station is the only practical alternative. Studies indicate that on-site shipment of LSA waste without DOT approval is possible. Although no vendor has been located who has a suitable cask, a vendor could design and fabricate a transportable, shielded cask by using the existing design criteria for a transportable cask. The detailed design and implementation of a cask/waste loading station within $\mathrm{REDC}$ is proceeding.

Design is proceeding on a cross-flow filtration system to remove insoluble radionuclides from liquids after the liquids have been decanted from the process tanks within REDC. Benchscale tests indicate that most of the radionuclides can be adequately removed by filtration, but verification tests for ruthenium will continue through FY 1994.

\subsubsection{Building 3025}

Through the Building 3025 Source Treatment project, a contingency plan will be provided for removing radioactive cobalt from waste generated in the Irradiated Materials Examination and Testing facility in Building 3025E. If access to the LLLW System through existing piping must be terminated, plans have been made to move LLLW from 3025E to the LLLW evaporator by trucking or bottling. If bottling should be required, radioactive cobalt would have to be removed from the waste prior to transport because of ORNL exposure limits for bottled waste. Two ion exchangers capable of selectively removing cobalt from the waste have been identified. Plans have been made for installation of a prototype system in a glovebox in 3025E. Additional cold test and tracer studies will be performed, followed, if appropriate, by hot testing. After testing, the system will be turned over to the Metals and Ceramics Division for evaluation. Additional issues that must be resolved include stability of the ion-exchange media during washing and dewatering and disposal of spent media. 


\section{LEAK TESTING}

The FFA requires that singly contained LLLW tank systems be leak tested periodically to demonstrate their continued ability to safely contain waste. DOE determined that monthly testing would adequately demonstrate the tanks' structural integrity.

\subsection{STATUS}

The leak test program for tanks is fully operational. Leak testing of piping began this fiscal year. The leak test algorithm for the tanks examines the compensated volume data over a prescribed period of time. The algorithm also includes checks for data quality and known environmental effects. On the basis of this data, the algorithm estimates the compensated volume rate and renders a pass or fail test decision. Two failed trials are required before a tank is deemed to have failed the test. Should a test failure occur, a second test is run. A tank that also fails the second test is considered to be leaking. The results of the tests may also be characterized as inconclusive, incomplete due to test requirements, or incomplete due to inflow. An inconclusive test decision can occur as a result of poor data quality or unexpected tank activity. A test can be declared incomplete due to test discrepancies if equipment malfunctions occur. A test can also be declared incomplete if inflow into the tank occurs during the test.

Developmental work on leak testing of piping started in 1992. Actual testing under the program began in January 1994. A variety of methods are used to test piping, depending upon the characteristics of each pipe segment. The primary test methods include helium tracer tests, enhanced volume balancing, gaseous pressure decay tests, and hybrids of these methods.

\subsection{ACCOMPLISHMENTS}

At the beginning of FY 1994, five singly contained tanks (W-16, WC-3, WC-7, WC-9, and WC-10) were being tested monthly. By the end of the fiscal year, 12 tanks were undergoing testing at least monthly (see Table A.1). A standardized leak test checklist was prepared to ensure that adequate preparation and controls to support the leak test are in place, including proper notifications, required equipment, personnel training, and health and safety requirements.

EPA and TDEC comments on the Detailed Leak Test Plan and Schedule for ORNL LLLW Active Pipelines (DOE/OR/01-1167) were addressed, and the D2 version of the document was issued in August. Leak testing of pipelines began in January 1994 in accordance with the milestone date. Through August, 11 segments had been tested. The results are shown in Table A.2.

\subsection{SCOPE OR SCHEDULE CHANGES}

The detailed leak test plan for piping lists several piping segments that cannot be leak tested by using the methods developed in the leak test plan. These segments represent only about $6 \%$ of the total volume of the LLLW piping. 


\section{OTHER FFA ACTIVITIES, CONCERNS, AND ISSUES}

\subsection{IMPROVED COMMUNICATION SYSTEM}

As part of the response to the issues surrounding the leak in the LLLW pipeline from the WC-10 Tank Farm, DOE developed a two-tiered process for improving communication with EPA and TDEC on FFA activities. Under the terms of the FFA, DOE is required to formally notify EPA and TDEC in the event of spills and releases of hazardous materials. These formal notifications will continue to be made, as required. In a plan submitted in October 1993, DOE proposed to provide additional, voluntary information to the responsible EPA and TDEC personnel by telephone, in parallel with the official notifications. Further, DOE proposed to provide information about plans and upcoming activities, such as pending correspondence, discussion of potential schedule changes, upcoming tests and demonstrations, difficulties in implementing FFA requirements, and potential concerns. This information will be provided verbally to the cognizant EPA and TDEC staff personnel. DOE also proposed to provide more detailed information and highlights to EPA and TDEC staff to supplement current requirements.

\subsection{TANK WC-14}

Samples of the liquid phase of the waste in Tank WC-14 that were taken in November 1992 indicated low-level polychlorinated biphenyl (PCB) contamination. Sludge samples collected in March and August 1993 indicated PCB levels three orders of magnitude higher than the levels in the liquid. The sludge samples also contained significant quantities of radioactive materials. The presence of PCBs in the tank was unexpected. An investigation completed in November 1993 revealed that the PCBs are not from any recent research or spill but are the result of a historical spill of unknown origin. In January 1994, DOE sent a request to EPA for an exemption from the antidilution provision of the PCB regulation to allow the aqueous phase of the tank contents to be discharged to the LLLW System. The exemption asks that all prior and subsequent liquid discharges from the LLLW System not be classified as Toxic Substances Control Act (TSCA) PCB waste and that solidified waste forms from the liquid waste system not be subject to TSCA PCB storage and disposal requirements. Calculations were prepared of the inventory of the tank contents, and they show that the PCB inventory is less than $0.3 \mathrm{lb}$. On May 2, DOE sent a letter to EPA and TDEC requesting confirmation that transfers from WC-14 will not cause the LLLW System to be considered a TSCA system. EPA is reviewing the request.

\subsection{TANK W-12}

LLLW Tank W-12 serves Building 3525. This tank is needed to support hot cell decontamination in FY 1995. In an October 1993 letter to DOE, EPA agreed to a one-time use of the tank if DOE would submit a decontamination plan to EPA and TDEC that provides for the removal of Tank W-12 contents immediately following building decontamination operations. In March DOE submitted a plan and justification for use of the 
tank for that purpose. EPA and TDEC approved the one-time use of the tank in accordance with the plan.

\subsection{TANK LA-104 REMOVAL FROM SERVICE}

LA-104 is a small tank located in Building 3047. No plans exist for future use of the tank, and a schedule and plan to remove it from service was prepared in FY 1994.

\subsection{TECHNICAL ADVISORY GROUP}

The ORNL FFA Technical Advisory Group (TAG) met in October 1993 and April 1994 to review the progress of selected FFA compliance activities. Specifically, the TAG critiqued a presentation of FFA progress based on a set of drawings that depict annual progress. The TAG made several general recommendations regarding the overall FFA program. They recommended that every effort be made to channel resources to those projects that are "required to reasonably protect the environment and assure the health and safety of site employees and the public." The TAG also recommended that consideration be given to permanently sealing every drain whose destination cannot be identified with certainty. They further recommended that "risk assessments be done on a priority basis so that the results can be used to set priorities between the many competing needs for funds ...."

\subsection{DRAIN SURVEY}

A followup to the 1992 survey of the inactive LLLW drains in all ORNL facilities was conducted to verify that the drains remain sealed. Performance criteria for sealing inactive LLLW drains were developed. The sealing criteria specify the required result and place the responsibility on the facility manager to determine the best method for effecting the seal. Annual inspections are planned to ensure that seals remain intact.

\subsection{ENVIROVIEW SOFTWARE}

The FFA team had an outside contractor design graphical data base software that can serve as a central source of FFA information that is widely accessible at ORNL. The software leads the user through a series of menu screens through which diagrams or data base information for all FFA tanks and piping can be accessed.

\subsection{TANK WC-9 LEVEL 2 OCCURRENCE}

During extremely heavy rainfall on December 4, 1993, a large volume of water entered Tank WC-9 (the tank level increased from $60 \%$ to $100 \%$ in approximately 2 hours). Construction activities associated with the installation of a bypass around the existing discharge pump channeled the rain into a sump that empties to WC-9. Construction in the area is complete, and the mechanism no longer exists for a recurrence of this event. 


\subsection{STACK/ISOTOPES AREA DRAIN CLOSURE}

As part of the effort to eliminate nonprogrammatic flow into the LLLW System, all drains in the 3039 Stack area that connected to the LLLW System were sealed or disconnected.

\subsection{TANK WC-8}

A pump associated with the WC-9 tank system required repair. Before the repair could be effected, the pipe line had to be flushed to reduce worker radiation exposure. Tank WC-8 was needed to collect the flushed waste. In January, EPA and TDEC approved one-time use of Tank WC-8 for this purpose. The installation was completed and liquids accumulated in the tank were transferred to the LLLW system in March. DOE filed a final report with EPA and TDEC, thereby concluding the one-time use of this tank.

\subsection{0-DAY REPORTS}

In January a small leak occurred in a pressure gauge connection on the Process Water System interface with the LLLW System in REDC (Building 7932). EPA and TDEC were notified via telephone within 24 hours as required by Appendix F of the FFA. A 30-day report was issued in February, thereby completing the notification requirements of the FFA. Due to the minor nature of the leak and the required repair, the system was returned to service when the actions outlined in the 30-day report were completed.

A 30-day report was filed in February to document a spill from Tank 7562. Before its removal from service, this tank served the Homogeneous Reactor Experiment facility (Building 7505). Readings from the tank's level monitor began to fluctuate widely in November. An inspection of the tank showed that it had filled above its normal operating level as a result of input from unknown sources. The tank level was lowered and an investigation was conducted to identify the source of the inflow. Before the investigation could be completed, the tank level again rose, and liquid was spilled from the tank's standpipe. The source of the inflow has been narrowed to one of three pits in Building 7505, but the specific mechanism through which inflow is reaching the tank is still under investigation.

\subsection{ELIMINATION OF NONPROGRAMMATIC FLOW}

Substantial progress was made in identifying sources of nonprogrammatic flow into Tank WC-10 that originate in the Isotopes Circle area. The correlation between tank inflow, rainfall, and temperature data collected from September through December 1993 was evaluated; approximately 50\% of the inflow into the tank over this period was correlated with rainfall events. The balance of the inflow remained relatively constant throughout the period. The investigation identified and subsequently eliminated some open drains, such as those at the old 3093 Building, from which collected rainwater was routed to the LLLW System. The investigation also ruled out some areas, such as the 3033 Annex Sump, that were suspected of contributing rainwater and groundwater to the LLLW System. A video inspection of the main LLLW header that serves the Isotopes Circle area was started this fiscal year. A 
miniature video camera was inserted into the pipeline through various cleanout ports. The line was checked at each port for the presence of flowing liquid, thus isolating the source of nonprogrammatic flow in the line.

\subsection{TANR F-501}

Tank F-501 has an overflow line that connects to Tank W-12. To decouple the tanks so that no unapproved flow could be routed to W-12, an expense-funded project was implemented in FY 1994 to install an isolation valve in the overflow line. Any overflow from Tank F-501 will now backup into Tank F-201, where it can be safely handled.

\subsection{CONTINGENCY PLANNING FOR THE GUNITE TANKS}

A study was prepared of the health, safety, and environmental impacts that would occur in the unlikely event of a dome collapse on one of the Gunite tanks in the south tank farm. The study, which was conducted as a best management practice, included an assessment of the potential consequences of dome collapse on groundwater, surface water, and air pathways. The results showed no appreciable off-site exposure. On-site exposures will be controlled through written procedures. The study showed that environmental, safety, and health systems at ORNL are capable of responding to and safely handling a postulated tank dome collapse.

\subsection{CATEGORY D TANK EXAMINATIONS}

A number of Category $\mathrm{D}$ tanks that were emptied several years ago were inspected this fiscal year and verified to still be empty: TH-1, TH-2, TH-3, W-15, W-16, W-17, and WC-1. These tanks may be candidates for early actions. 
APPENDIX A

PERFORMANCE INDICATORS 
Table A.1. Tank leak test results

\begin{tabular}{|c|c|c|c|c|c|c|c|c|c|c|c|c|}
\hline Tank & OCT & NoV & DEC & JAN & FEB & MAR & APR & MAY & JUN & JUL & AUG & SEP \\
\hline W-12 & & & I & $\mathbf{N}$ & $\mathbf{P}$ & $\mathbf{P}$ & $\mathbf{P}$ & I & I & $\mathbf{P}$ & I & \\
\hline W-16 & $\mathbf{P}$ & NT & NT & $\mathbf{P}$ & $\mathbf{P}$ & $\mathbf{P}$ & $\mathbf{P}$ & $\mathbf{P}$ & $\mathbf{P}$ & $\mathbf{P}$ & $\mathbf{P}$ & \\
\hline WC-2 & & & $\mathbf{P}$ & $\mathbf{P}$ & $\mathbf{P}$ & $\mathbf{P}$ & $\mathbf{P}$ & $\mathbf{P}$ & $\mathbf{P}$ & $\mathbf{P}$ & $\mathbf{P}$ & \\
\hline WC-3 & $\mathbf{P}$ & $\mathbf{P}$ & NT & $\mathbf{P}$ & $\mathbf{P}$ & $\mathbf{P}$ & $\mathbf{P}$ & $\mathbf{P}$ & $\mathbf{P}$ & $\mathbf{P}$ & $\mathbf{P}$ & \\
\hline WC-7 & $\mathbf{P}$ & $\mathbf{P}$ & $\mathbf{P}$ & $\mathbf{P}$ & $\mathbf{P}$ & $\mathbf{P}$ & $\mathbf{P}$ & $\mathbf{P}$ & $\mathbf{P}$ & $\mathbf{P}$ & $\mathbf{P}$ & \\
\hline WC-9 & $\mathbf{P}$ & $\mathbf{P}$ & I & $\mathbf{P}$ & $\mathbf{P}$ & $\mathbf{P}$ & $\mathbf{P}$ & $\mathbf{P}$ & $\mathbf{P}$ & $\mathbf{P}$ & $\mathbf{P}$ & \\
\hline WC-10 & $\mathbf{P}$ & I & $\mathbf{N}$ & $\mathbf{N}$ & I & I & I & I & $\mathbf{N}$ & I & I & \\
\hline WC-19 & & & $\mathbf{N}$ & $\mathbf{N}$ & $\mathbf{N}$ & $\mathbf{P}$ & $\mathbf{I}^{\mathbf{2}}$ & $\mathbf{I}^{\mathbf{a}}$ & $\mathbf{N}^{2}$ & $I^{2}$ & $\mathrm{I}^{*}$ & \\
\hline $\mathrm{T}-1$ & & & $\mathbf{P}$ & $\mathbf{P}$ & $\mathbf{P}$ & $\mathbf{P}$ & $\mathbf{P}$ & $\mathbf{P}$ & * & * & * & \\
\hline$T-2$ & & & $\mathbf{N}$ & $\mathbf{P}$ & $\mathbf{P}$ & $\mathbf{P}$ & I & I & $*$ & $*$ & * & \\
\hline $2026 A$ & & & & & $\mathbf{P}$ & $\boldsymbol{P}$ & $\mathbf{P}$ & $\mathbf{P}$ & $\mathbf{P}$ & $\mathbf{P}$ & $\mathbf{P}$ & \\
\hline HFIR & & & & & & $I^{b}$ & $\mathbf{I}^{\mathbf{b}}$ & $\mathbf{I}^{b}$ & $I^{b}$ & & & \\
\hline
\end{tabular}

P: Passed

NT: Test not completed due to test discrepancies

I: Inconclusive

$\mathrm{N}$ : Inflow present

F: Fail

*Tank has been tested, and data are currently being analyzed.

"Recent tests on Tank WC-19 have been inconclusive or incomplete because inflow to the tank from groundwater has affected the test results. The successful test in March was very positive, and the tank is not thought to be leaking to the environment.

bests on the HFIR tank have been inconclusive because the tank continuously receives inflows that corrupt the test results. Data quality problems have also been encountered in recent tests. This tank is not thought to be leaking to the environment. 
Table A.2. Pipeline leak test results

\begin{tabular}{|c|c|c|c|c|c|}
\hline Tank system & Inflow node & Outflow node & Test result & Date & Test method \\
\hline WC-20 & $\begin{array}{l}\text { Valve box in } \\
\text { south parking lot }\end{array}$ & Building 7567 & $I^{2}$ & $1 / 26 / 94$ & GPD \\
\hline WC-20 & Building 7567 & & $P$ & $9 / 4 / 94$ & GPD \\
\hline WC-2 & Building 3038 & S17N2 & $P$ & $8 / 31 / 94$ & EVB \\
\hline WC-2 & Building 3038 & S1N14 & $\mathbf{P}$ & $8 / 94$ & GPD \\
\hline WC-9 & $\begin{array}{l}\text { Building } 3503 \text {, } \\
\text { 2nd floor }\end{array}$ & Tank WC-9 & $P$ & $5 / 10 / 94$ & Hybrid EVB \\
\hline WC-3 & $\begin{array}{l}\text { Building } 3523 \mathrm{C} \\
\text { 2nd floor }\end{array}$ & Tank WC-3 & $\mathrm{P}$ & $5 / 26 / 94$ & $\begin{array}{l}\text { Hybrid } \\
\text { EVB }\end{array}$ \\
\hline WC-7 & $\begin{array}{l}\text { Building } 3504 \\
\text { Rm. } 106\end{array}$ & Tank WC-7 & $F^{b}$ & $4 / 6 / 94$ & Visual \\
\hline$W-16$ & $\begin{array}{l}\text { Building } 3026 \text {, } \\
\text { first floor lab }\end{array}$ & Tank W-16 & $I^{\mathrm{c}}$ & $6 / 15 / 94$ & GPD \\
\hline WC-10 & Valve Box 1 & Tank WC-10 & $\mathrm{P}$ & $6 / 29 / 94$ & GPD \\
\hline L-11 & Building 3544 & & $\mathbf{P}$ & $7 / 94$ & GPD/Helium \\
\hline $\mathrm{L}-11$ & Valve Box 1 & Building 3544 & $F^{d}$ & $7 / 12 / 94$ & GPD \\
\hline $\mathrm{L}-11$ & Valve Box 1 & Building 3544 & $P^{d}$ & $7 / 19 / 94$ & $\begin{array}{l}\text { Helium } \\
\text { tracer test }\end{array}$ \\
\hline
\end{tabular}

\footnotetext{
P: $\quad$ Passed

I: Inconclusive

F: Fail
}

'The GPD test for the WC-20 discharge line resulted in an inconclusive, due to poor data quality (unknown volume of liquid in pipeline prohibited accurate calculation of the leak rate). However, the pipeline did appear to hold pressure at an acceptable level. The GPD test will be re-scheduled in consideration of construction activities at the Evaporator Complex.

'This leak occurred during a test of an inactive drain line that has not been used in more than three years. Health Physics surveyed the leaked water and verified that it was uncontaminated. As a precaution, EPA and TDEC were notified. Because no hazardous or radioactive material was released, no official 30-day report was filed.

The EVB test on the gravity line from Building 3026 to Tank W-16 resulted in an inconclusive, due to an apparent inflow into the tank. This pipeline is our of service and is expected to remain as such. Therefore, the pipeline will not be re-tested and the drain will be sealed. The W-16 tank system will remain a Category $C$ system. In the event the line needs to be used, an EVB test will be conducted prior to usage.

${ }^{d}$ This line segment did not pass the gas pressure decay test, but due to the characteristics of the data collecled, the failure was suspected to result from leaks through the boundary valve seats rather than a hole in the pipe. A helium tracer test was run on $7 / 19$, and no leakage from the pipe was detected. In accordance with the leak test protocol, this confirmed that the pipe segment was not leaking to the environment. 
DOE/OR/01-1291\&D1

ORNL/ER-252\&D1

\section{DISTRIBUTION}

1. H. L. Boston

2. A. D. Clay

3. C. E. Devore

4-6. J. T. Etheridge

7. C. E. Frye

8. P. J. Halsey

9-11. D. M. Matteo

12-14. T. H. Monk

15-16. P. T. Owen

17. B. D. Patton

18-19. M. R. Peet

20. S. M. Robinson

21. C. B. Scott

22. P. S. Wood

23. Central Research Library

24. ORNL ER Document Management Center

25. Central ER Document Management Center

26. Laboratory Records Department

27. ORNL Patent Section

28. Office of Assistant Manager for Energy Research and Development, DOE Oak Ridge Operations Office, P.O. Box 2001, Oak Ridge, TN 37831-8600

29. C. Mims, DOE Oak Ridge Operations Office, P.O. Box 2001, Oak Ridge, TN 37831-8541

30. L. L. Radcliffe, DOE Oak Ridge Operations Office, P.O. Box 2001, Oak Ridge, TN 37831-8541

31-32. L. C. M. Roddye, DOE Oak Ridge Operations Office, P.O. Box 2001, Oak Ridge, TN $37831-8541$

33. J. M. Singleton, H\&R Technical Associates, Inc., P.O. Box 4159, Oak Ridge, TN $37831-4159$

34. R. C. Sleeman, DOE Oak Ridge Operations Office, P.O. Box 2001, Oak Ridge, TN 37831-8541

35. Douglas Underwood, DOE Oak Ridge Operations Office, P.O. Box 2001, Oak Ridge, TN 37831-8541

36-37. Office of Scientific and Technical Information, P.O. Box 62, Oak Ridge, TN 37831 